\title{
Editorial
}

\section{LA IMPORTANCIA DE LOS SEMILLEROS DE INVESTIGACIÓN}

Juan Carlos Villalba Cuéllar (Editor)
Andrés González Serrano (Coeditor)

Los semilleros de investigación son una nueva estrategia académica para abordar el conocimiento dejando de lado escuelas tradicionales y dando paso a la enseñanza activa y constructiva. Son un espacio que permite a sus integrantes, estudiantes y docentes -sobre todo a los primeros-, una participación real, controlada, guiada y procesual del binomio enseñanza-aprendizaje que prioriza la libertad, la creatividad y la innovación para el desarrollo de nuevos esquemas mentales y métodos de aprendizaje.

A través de la tertulia, el debate y el diálogo con el profesor, el investigador (llámese estudiante, semilla, joven investigador o auxiliar de investigación) aprende a aprender, aprende a investigar y descubre o desarrolla el conocimiento. Se podría afirmar que los semilleros son más enriquecedores que el aula misma.

La investigación formativa unida a los semilleros de investigación promueve el aprendizaje autónomo y creativo. Sin embargo, los semilleros no solo contribuyen a formar en investigación, también se forman profesionales con mayor calidad humana, sociabilidad y compromiso social.

La productividad y desarrollo de los semilleros de investigación en los claustros universitarios, inicialmente dependen del docente a cargo de los mismos, este debe ser capaz de construir un saber pedagógico a través de la acción, para ello hará uso de la reflexión, la experimentación, la escritura y el diálogo, proceso que se debe dar en ciclos sucesivos de interrelación con el estudiante.

Los semilleros ayudan a la apropiación de una cultura académica e institucional de procesos formativos y científicos; además, en ellos se puede dar una academia crítica y forjar verdaderas líneas y grupos de investigación.

Un semillero formará también a los futuros investigadores y allí encuentra una de sus grandes virtudes, pues un centro de investigaciones que cuente con ciclos continuos de semilleros contará claramente con el insumo para producir investigación de calidad en las siguientes generaciones.

La utilidad de los semilleros alcanza a la institución, al docente y al estudiante. Entre otros beneficios, los semilleros facilitan el trabajo independiente, en equipo y dirigido; crean nuevas estrategias de investigación, afianzan las herramientas metodológicas, experimentan procesos investigativos y de aprendizaje, enriquecen el proceso docencia e investigación, socializan los productos de investigación y fortalecen los espacios académicos y de aprendizaje.

El estudiante que decida pertenecer a un semillero de investigación y ejecutar un proyecto puede aprender a plantear problemas, formular hipótesis, recopilar y sintetizar información, observar, indagar, realizar entrevistas y encuestas, consultar bases de datos y presentar sus productos de investigación. Competencias que sin duda le ayudarán a ser un mejor profesional y a desplegar capacidades investigativas que se fortalecen con la investigación misma. Por su parte, el docente a través de la interacción potencializará sus habilidades investigativas y sus estrategias pedagógicas.

Ahora bien, los semilleros de investigación necesitan gran protección institucional, pues se requieren condiciones propicias para que tanto 
el docente investigador como los investigadores semilla puedan adelantar con tranquilidad el proceso de investigación formativa.

Así las cosas, las ventajas y bondades que ofrecen los semilleros de investigación invitan a su implementación, mejora y fortalecimiento al interior de las instituciones de educación superior, en aras de formar mejores personas, mejores profesionales y de generar procesos en la actividad investigativa institucional que permitan al investigador-semilla considerarla como una opción en el ejercicio profesional. 